\title{
MEMORI EPISODIK SEBAGAI TERRA INCOGNITA YANG MEMBATASI NEUROTEKNOLOGI
}

\section{Siti Azri Ulmi Ramadhanty dan Harsawibawa Albertus}

Universita Indonesia Depok Jawa Barat, Indonesia

Email: azriramadhanty@gmail.com dan harsawibawa.albertus@ui.ac.id

\begin{abstract}
One of the implications of the development of neuroscience is neurotechnology. Initially, neurotechnology aims to address brain dysfunction, such as overcoming Alzheimer's disorders that cause memory loss. However, neurotechnology seems to go a step further, i.e. it not only serves to repair brain damage, but also to correct mental phenomena connected to the brain or that are "produced" by the brain, which are associated with memory. Based on this, the question arises, whether it is possible that neural technology improves and replaces human memory. Nevertheless, these neurotechnical efforts seem to ignore the meaning of memory itself, including what actually "builds" memory, so that humans can have different feelings of memory. Thus, to answer this problem, the author first interprets memory explicitly through a clear difference between semantic memory and episodic memory, to show that human memory, which is an episodic memory, is associated with qualitative states. Second, by describing the opportunities presented by neurotechnology through mind experimentation regarding neuron replacement by electronic chips, to demonstrate the impossibility of neurotechnology functioning in the same way as neurons in the brain that produce episodic memory with these qualitative states. Therefore, based on these arguments, it will be known that neurotechnology is actually impossible to improve, especially replacing human memory.
\end{abstract}

Keywords: qualitative states; experience; episodicmemory; semantic memory; neurotechnology

\begin{abstract}
Abstrak
Salah satu implikasi perkembangan ilmu saraf adalah neuroteknologi. Awalnya, neuroteknologi bertujuan untuk mengatasi disfungsi otak, seperti mengatasi gangguan Alzheimer yang menyebabkan hilang ingatan. Namun, neuroteknologi tampaknya melangkah lebih jauh, yaitu tidak hanya berfungsi untuk memperbaiki kerusakan otak, tetapi juga untuk memperbaiki fenomena mental yang terhubung ke otak atau yang "diproduksi" oleh otak, yang terkait dengan memori. Berdasarkan hal ini, timbul pertanyaan, apakah mungkin teknologi saraf meningkatkan dan menggantikan memori manusia. Kendati demikian, upaya neuroteknologi tersebut tampaknya mengabaikan arti dari ingatan itu sendiri, termasuk apa yang sebenarnya "membangun" ingatan, sehingga manusia dapat memiliki perasaan ingatan yang berbeda. Dengan demikian, untuk menjawab masalah ini, penulis pertama-tama menafsirkan memori secara eksplisit melalui perbedaan yang tegas antara memori semantik dan memori episodik, untuk menunjukkan bahwa memori manusia, yang
\end{abstract}


merupakan memori episodik, terkait dengan qualitative states. Kedua, dengan mendeskripsikan peluang yang dihadirkan oleh neuroteknologi melalui eksperimentasi pikiran mengenai penggantian neuron oleh chip elektronik, untuk menunjukkan ketidakmungkinan neuroteknologi berfungsi dengan cara yang sama seperti neuron di otak yang menghasilkan memori episodik dengan qualitative states ini. Oleh karena itu, berdasarkan argumentasi tersebut, akan diketahui bahwa neuroteknologi sebenarnya tidak mungkin dapat memperbaiki, terutama mengganti ingatan manusia.

Kata kunci: qualitative states; pengalaman; memori episodik; memori semantik; neuroteknologi

Coresponden Author

Email: azriramadhanty@gmail.com Artikel dengan akses terbuka dibawah lisensi

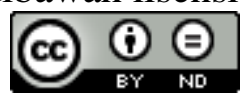

\section{Pendahuluan}

Seiring berjalannya waktu, dunia selalu mengalami perkembangan. Salah satunya adalah perkembangan ilmu pengetahuan dan teknologi yang semakin masif, yang menjadi titik awal bagi perkembangan neurosains. Salah satu tujuan dari perkembangan neurosains tersebut adalah untuk mengungkap hubungan pikiran (termasuk di dalamnya kecerdasan) dan otak, hingga betujuan untuk menciptakan sesuatu yang dapat menyamai bahkan melampaui kemampuan manusia dalam hal berpikir, yakni AI (artificial intelligence) Hal ini dilatarbelakangi oleh keyakinan bahwa mungkin dan bisa diciptakannya komputer yang kecerdasannya sama dengan manusia, bahkan melebihinya. Selain itu, banyak dari ilmuwan neurosains yang mengatakan bahwa otak tidaklah lebih daripada sebuah komputer yang sangat rumit. Namun kenyataannya, kita tahu bahwa "kerumitan" komputer sangat berbeda jauh dengan kerumitan otak.

Neurosains adalah studi ilmiah tentang saraf dan secara umum menjanjikan pemahaman yang berkembang tentang cara kerja otak (Rainey \& Erden, 2020) Studi ini juga merupakan bentuk pengembangan lebih lanjut dari ilmu biologi yang kemudian melahirkan serangkaian sub-studi lainnya, terutama berkaitan dengan psikiatri, psikologi, matematika, juga filsafat (khususnya mengenai studi philosophy of mind) dan memiliki tujuan yang salah satunya adalah mengungkap bagaimana kecerdasan manusia berkaitan erat dengan fungsi jutaan neuron yang saling terhubung di otak, yang pada akhirnya memungkinkan adanya "replika" manusia seperti kecerdasan buatan (artificial intelligence). Hal ini disebabkan karena menurut para ahli neurosains, untuk memahami kecerdasan yang merupakan bagian dari pikiran, yakni dengan memahami bagianbagian otak dan fungsinya. Neurosains adalah disiplin ilmiah yang layak untuk menyematkan proses mental dengan mempelajari aktivitas otak (Manzotti \& Moderato, 2010). Artinya, dengan memahami struktur-struktur di otak dan fungsinya, serta bagaimana neuron itu saling terhubung dan bekerja, dapatlah dipahami mengenai proses mental, terlebih bagaimana dapat dihasilkannya kemampuan berpikir dan mengingat. 
Lebih jauh, memahami otak dapat menghantarkan kita pada pemahaman tentang kesadaran (atau bahkan pikiran). Sebab, setiap keadaan sadar dipahami melalui beberapa aktivitas saraf; pemahaman yang lebih besar tentang keadaan sadar harus muncul dari pemahaman yang lebih besar tentang otak (Rainey \& Erden, 2020).

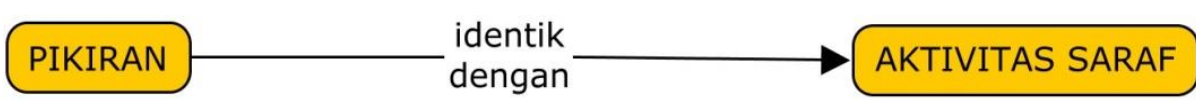

\section{Bagan 1 Keidentikkan Pikiran dan Aktivitas Saraf (Diolah sendiri dari berbagai sumber)}

Dari latar belakang tersebut, neurosains mencoba menciptakan pengembangan lebih lanjut, dengan contohnya yang paling umum adalah jaringan saraf tiruan (artificial neural network) yang berfungsi sebagai unit pemerosesan sederhana yang dirancang untuk meniru operasi neuron individu (Carter, 2007). Sama seperti neuron asli, unitunit di dalam jaringan neuron tiruan ini memiliki fungsi yang dihubungkan di dalam beberapa lapisan, yakni lapisan input dan lapisan output. Di antara lapisan input dan lapisan output itu, ada yang disebut sebagai lapisan "tersembunyi" yang berfungsi untuk menengahi dua lapisan tadi. Cara kerja dari jaringan saraf tiruan ini sebenarnya sama dengan jaringan saraf yang ada di otak, tetapi tentunya sangat deskriptif dan matematis karena diterjemahkan ke dalam fungsi-fungsi matematika tertentu dan angka-angka biner. Pemrosesan informasi di jaringan saraf tiruan dicapai melalui penyebaran aktivasi di sepanjang koneksi jaringan dengan setiap simpul dalam jaringan memiliki tingkat aktivasi yang dipengaruhi oleh aktivasi yang diterimanya dari simpul lain yang terhubung dengannya (Carter, 2007). Pada dasarnya, cara kerja dari jaringan saraf tiruan inilah yang menjadi titik berangkat untuk melakukan pengembangan neurosains lebih lanjut, yakni dalam rangkaian human enhancement, salah satunya ialah neuroteknologi yang "didedikasikan" untuk memperbaiki dan mengganti ingatan manusia. Hanya saja, inilah yang memunculkan pertanyaan: apakah mungkin?

Di dalam penyusunan tulisan ini, penulis terinspirasi dari beberapa penelitian sebelumnya yang menjadi salah satu acuan penulis dalam melakukan penelitian selanjutnya, sehingga penulis dapat memperkaya teori yang digunakan untuk mengkaji penelitian yang dilakukan. Penelitian-penelitian terdahulu yang menjadi acuan dan titik berangkat bagi penulis adalah sbb.:

Penelitian yang dilakukan oleh (Nematzadeh, Ruder, \& Yogatama, 2020), yakni "On Memory in Human and Artificial Language Processing Systems". Di dalam penelitian ini, ditekankan adanya persamaan antara memori manusia dan AI dalam hal pengambillan, penyandian, dan penyimpanan informasi. Namun, memori manusia memiliki fungsi yang terpisah-pisah, berupa memori kerja, memori semantik, dan memori episodik yang ketiganya saling berinteraksi secara terstruktur dalam pemrosesan bahasa. Sementara itu, memori pada AI tercampur menjadi satu. Oleh karenanya, penelitian tersebut berupaya untuk membuktikan bahwa sistem pemrosesan 
bahasa generasi mendatang dapat mengintegrasikan berbagai jenis memori sebagai modul terpisah dengan fungsi yang menyerupai memori dalam pemrosesan bahasa manusia, mengacu pada properti yang diperlukan dari sistem penyimpanan dalam bentuk ruang terstruktur dan kemampuan untuk melupakan, serta melakukan abstraksi sama seperti otak manusia (Nematzadeh et al., 2020).

Penelitian selanjutnya dilakukan oleh (Whitworth \& Ryu, 2009), yakni “A Comparison of Human and Computer Information Processing". Di dalam penelitian ini, dipaparkan secara lengkap persamaan dan perbedaan antara fungsi-fungsi dan cara kerja otak dan komputer, serta bagaimana sistem pemerosesan informasi di antara keduanya. Namun, walaupun komputer sedikit banyaknya "mirip" dengan otak manusia, tetapi tentu perbedaan-perbedaan yang signifikan antara komputer dan otak tetap membuat otak jauh melampaui komputer. Penulis menegaskan bahwa kita mungkin dapat membuat komputer yang sangat cerdas. Akan tetapi, membuat komputer yang "bisa melakukan segalanya" seperti manusia tampaknya tidak perlu dan tidak diinginkan karena komputer tidak dapat bertanggung jawab atas tindakan mereka; masa depan komputasi terletak pada pengidentifikasian aktivitas manusia yang signifikan dan perancangan sistem komputer untuk mendukungnya, sehingga kita tidak membutuhkan keunggulan komputer, tetapi keunggulan manusia-komputer (Whitworth \& Ryu, 2009).

Kemudian, penelitian yang dilakukan oleh (Rainey \& Erden, 2020), yakni "Correcting the Brain? The Convergence of Neuroscience, Neurotechnology, Psychiatry, and Artificial Intelligence”. Penelitian ini dilakukan untuk melihat kemungkinan bahwa praktik pengobatan dalam bidang psikiatri dapat dilakukan dengan melibatkan teknologi saraf atau neuroteknologi. Hal ini merupakan sebuah cara baru dalam penilaian pasien dan diagnosis klinis. Neuroteknologi menjanjikan pengobatan yang cepat, efisien, dan komprehensif yang tidak disediakan oleh observasi konvensional terhadap pasien, yakni dengan cara merekam dan memproses sinyal otak sebagai dasar untuk mengevaluasi fungsi umum dan perilaku pasien. Tampaknya penelitian ini bersifat begitu deskriptif, tetapi penulis memberikan penegasan bahwa tetap ada sisi normatif yang harus diperhatikan dalam mengintegrasikan neuroteknologi ke dalam pengobatan psikiatri; penggunaan teknologi di dalam pengobatan manusia tetap harus mempertimbangkan dan didasarkan pada norma-norma (Rainey \& Erden, 2020).

Selanjutnya, penelitian yang dilakukan oleh (Manzotti \& Moderato, 2010), yakni "Is Neuroscience Adequate as the Forthcoming "Mindscience"?". Penelitian ini bertujuan untuk membuktikan bahwa ilmu saraf memiliki banyak kekurangan untuk dijadikan sebagai ilmu tentang pikiran: ruang lingkup pikiran berada di luar ilmu saraf. Menurut penulis, penelitian ini tidak cukup untuk mendukung pendirian metafisik apa pun tentang pikiran; penelitian ini bertujuan untuk menentang asumsi-asumsi keberhasilan ilmu saraf yang tidak terbantahkan. Menurut penulis, neurosains tidak cukup sebagai ilmu tentang pikiran, sebab sistem saraf tidak cukup dijustifikasi sebagai dasar fisik dari pikiran (Manzotti \& Moderato, 2010). 
Selain beberapa penelitian terdahulu di atas, beberapa rujukan juga menjadi referensi bagi penulis untuk menjawab permasalahan yang diangkat, yaitu:

The Routledge Handbook of Philosophy of Memory (Bernecker \& Michaelian, 2017), dimana Werning dan Cheng (p. 9) menegaskan kategorisasi mengenai memori, yaitu kategori skalar, alamiah, dan hirarkis. Pengkategorisasian memori ini dijadikan sebagai titik berangkat di dalam penelitian untuk memberikan penegasan perbedaan antara memori dan ingatan.

Minds and Computers (Carter, 2007) memaparkan bahwa sistem pemrosesan informasi oleh saraf di otak mirip dengan sistem pemrosesan informasi jaringan komputer. Selain itu, tulisan ini juga menunjukkan adanya sistem saraf tiruan yang dibuat dengan fungsi dan mekanismenya menyerupai saraf-saraf otak manusia. Namun, pada akhir tulisannya, Carter menekankan bahwa kendati dapat dibuat jaringan saraf tiruan yang dapat berfungsi mirip dengan saraf sesungguhnya, tetap saja jaringan saraf tiruan itu mengesampingkan fenomena-fenomena mental, seperti emosi, sensasi, dan perasaan. Tulisan Carter ini yang menjadi referensi bagi penulis untuk merespons neuroteknologi sebagai penggantian ingatan manusia.

Truly Human Enhancement; A Philosophical Defense of Limits (Santagata et al., 2014) memberikan penjelasan tentang human enhancement secara umum yang amat membantu penulis untuk melihat lebih jauh mengenai permasalahan neuroteknologi sebagai salah satu bentuk dari human enhancement itu sendiri. Agar juga mengangkat tentang betapa krusialnya memori otobiografi yang mendapatkan pengaruh dari radical enhancement. Terlalu banyak peningkatan yang secara aktif pada otak manusia justru akan mengganggu kelangsungan memori otobiografi (Santagata et al., 2014). Individu yang mengalami peningkatan ini kemungkinan masih bisa mempertahankan ingatan otobiografinya, tetapi lagi-lagi, apakah ingatan itu masih memiliki 'rasa' yang sama?

The Conscious Mind in Search of a Fundamental Theory (Chalmers, 1996). Dalam sebuah eksperimentasi pikiran, yakni penggantian neuron dengan sebuah chip elektronik yang terbuat dari silikon, Chalmers berupaya untuk menjelaskan permasalahan fading qualia sebagai suatu kemasukakalan dan sangat mungkin bisa diterima. Yang dimaksud dengan fading qualia atau "qualia yang memudar", dalam pengertian Chalmers, merupakan pemudaran kesadaran secara bertahap selama serangkaian kasus penggantian neuron dengan chip elektronik silikon, sebelum akhirnya kesadaran itu menghilang (Chalmers, 1996). Eksperimentasi pikiran ini menjadi landasan bagi penulis untuk mengkritik dan menyangkal upaya neuroteknologi dalam penggantian ingatan manusia.

Dengan demikian, berdasarkan beberapa penelitian terdahulu dan rujukan yang penulis gunakan sebagai referensi, maka apa yang ingin disampaikan di dalam tulisan ini adalah untuk melihat bahwa bagaimanapun manusia dengan segala ingatan yang dimilikinya tidak akan pernah bisa digantikan. Sebab, ingatan manusia memiliki "sejumlah" qualitative states, seperti perasaan, emosi, dan sensasi. Sehingga, perlu dibedakan antara memori dan ingatan untuk dapat memahami mengapa ingatan demikian tidak bisa digantikan dengan teknologi saraf yang diupayakan. 
Berbeda dengan penelitian-penelitian terdahulu yang informatif dan deskriptif, penelitian ini dimaksudkan untuk memberi penjelasan dan pemahaman yang lebih argumentatif dan tentunya filosofis. Adanya pembedaan di antara komputer dan otak memang penting untuk diuraikan, tetapi hanya sebagai titik berangkat bagi penulis untuk melihat konsekuensi dari teknologi yang diciptakan dengan upaya menjadi bagian dari ingatan manusia. Selain itu, penelitian ini juga mendukung penelitian-penelitian sebelumnya, seperti penelitian yang dilakukan oleh (Manzotti \& Moderato, 2010), yakni mendukung kelemahan dari asumsi neurosains yang selama ini seolah-olah tidak terbantahkan. Terlebih melalui neuroteknologi, penulis ingin menegaskan bahwa teknologi secanggih apa pun tampaknya sulit untuk diserupakan dengan otak, apalagi dapat bekerja serupa dan menghasilkan karakteristik mental seperti ingatan.

\section{Metode Penelitian}

Ada dua metode yang digunakan di dalam tulisan ini untuk menjawab permasalahan apakah neuroteknologi sebenarnya dapat memperbaiki dan mengganti ingatan manusia. Pertama, metode distingsi konseptual, yakni membedakan secara ketat konsep memori dan ingatan yang bersifat ekuivokal dan yang selama ini dipahami secara tumpang tindih. Namun, sebelum membedakan kedua konsep tersebut, perlu diketahui bahwa konsep memori itu sendiri merupakan bentuk konsep yang sifatnya terlalu umum dan terbuka, sehingga menghasilkan begitu banyak interpretasi yang pada akhirnya menghasilkan pengertian atau makna yang tidak ketat. Konsep semacam ini disebut Baggini dan Fosl sebagai konsep "tipis" yang dengan demikian memungkinkan variasi yang luas dalam bagaimana ia dipahami (Fosl \& Baggini, 2020). Oleh sebab itu, konsep memori perlu diperjelas lebih lanjut, yakni memaknainya secara lebih ketat dan substantif, sehingga dapatlah ditarik ke dalam distingsi antara memori semantik dan memori episodik, di mana yang kedua ini merupakan justifikasi mendalam terkait dengan apa itu ingatan yang membedakannya dengan memori (semantik). Hal ini dikarenakan akan diketahui bahwa ingatan berkaitan dengan pengalaman masa lalu yang di dalamnya melibatkan rasa atau karakteristik dari qualitative states, sedangkan memori semantik merupakan bentuk dari memory-knowledge yang tidak melibatkan rasa tertentu. Melalui distingsi konseptual ini, pengertian tentang memori dan ingatan yang tumpang tindih dapat dihindari sebab dihasilkan definisi yang jelas pembatasannya dan tidak bersifat ambigu.

Kedua, metode eksperimentasi pikiran didukung melalui pembuktian yang dilakukan oleh Chalmers tentang fading qualia, yakni dengan mengimajinasikan bahwa neuron-neuron di otak digantikan oleh sejumlah chip elektronik yang bekerja serupa dengan fungsi dan aktivitas neuron-neuron tersebut. Sama seperti eksperimentasi ilmiah, metode eksperimentasi pikiran juga ditujukan untuk memicu ingatan tentang anomali (Daly, 2010), khususnya berkaitan dengan pembuktian bahwa neuroteknologi melalui chip elektronik tidak serta-merta dapat memperbaiki dan mengganti ingatan manusia. Dengan kata lain, metode eksperimentasi pikiran melahirkan adanya pembuktian yang sifatnya a priori dan menjadi argumentasi untuk memperkuat klaim 
filosofis mengenai ketidakmungkinan atas upaya yang dilakukan oleh neuroteknologi tersebut sebagai responsnya terhadap ingatan manusia.

\section{Hasil dan Pembahasan}

\section{Persamaan dan Perbedaan Antara Otak dan Komputer: Sebuah Titik Berangkat}

Seperti yang telah dijelaskan sebelumnya, salah satu tujuan dari neurosains adalah mengungkap hubungan antara pikiran dan aktivitas neuron, sebagai bagian dari pengembangan sains untuk dapat menciptakan mesin yang dapat "meniru" kecerdasan manusia, bahkan mungkin melampauinya. Hal ini dikarenakan hubungan antara neuron dan pikiran sangat jelas dan masuk akal. Memang, ada beberapa hal yang menjadi poin penting mengapa otak "bisa" disamakan dengan perangkat komputer terutama oleh para ilmuwan neurosains dan kognitif, yaitu (Whitworth \& Ryu, 2009). Neuron ialah perangkat yang bisa berada dalam keadaan on/off untuk merepresentasikan informasi digital.

a. Neuron memiliki padanan bagiannya di dalam sebuah komputer digital berupa rangkaian elektronik yang disebut sebagai gerbang logika (logic gate).

b. Otak memiliki saluran masukan (input) / keluaran (output), seperti halnya komputer.

c. Otak bekerja dengan listrik sama halnya dengan komputer.

d. Jika komputer memiliki banyak transistor, maka otak memiliki banyak neuron (sekitar 1010 lebih banyak daripada jumlah orang di dunia).

Berdasarkan persamaan-persamaan tersebut, bisa dikatakan bahwa "secara sistem", otak dan komputer memiliki struktur dan fungsi yang nyaris sama. Namun, tetap perlu di garisbawahi adanya perbedaan-perbedaan di antara keduanya dan inilah yang pada akhirnya menjadikan komputer dan otak harus dibandingkan secara signifikan. Yang paling utama adalah perbedaannya dalam hal 'desain'. Dalam arti, sistem komputer berevolusi selama sekitar 60 tahun, sementara otak manusia telah berevolusi selama jutaan tahun, dan telah diuji dengan ketat selama berlangsungnya kehidupan dalam kurun waktu berabad-abad (Whitworth \& Ryu, 2009). Atau, dapat dikatakan pula bahwa desain komputer itu tidak konsisten seperti halnya otak manusia yang berevolusi secara genetis, sebab perancangan komputer bergantung pada si pendesain.

Lebih lanjut, semua program yang yang dijalankan oleh sebuah mesin komputer merupakan bentuk dari sistem komputasi dan salah satu program yang dijalankan adalah berkaitan dengan pengolahan informasi yang kemudian disimpan dalam kotak penyimpanan sementara, yang disebut sebagai memori. Oleh karena itu, perlu ditekankan bahwa walaupun otak manusia itu "tampak" seperti hardware komputer yang dapat menyimpan segala informasi, keduanya tetap berbeda dan harus ditegaskan dengan ketat. Memori komputer menyimpan berbagai informasi berupa data-data (komputasi), tetapi semua data itu tercampur menjadi satu. Ini merupakan salah satu alasan mengapa para ilmuwan berkeinginan untuk membuat 
suatu pemisahan penyimpanan dalam komputer dengan tujuan untuk memfasilitasi pencarian yang lebih cepat, mirip dengan pengambilan memori manusia dan penyimpanan harus dapat mengelola kompleksitas ukurannya secara dinamis dengan 'melupakan' atau 'mengompresi' untuk membentuk 'abstraksi' sama seperti otak manusia (Nematzadeh et al., 2020). Tentunya hal ini terinspirasi dari pembagian di dalam otak yang sangat teratur atas "memori": lobus frontal sebagai tempat penyimpanan memori jangka pendek dan lobus parietal, osipital, serta temporal sebagai tempat penyimpanan memori jangka panjang, juga bagian yang terlibat dalam pengkodean informasi baru, yakni hipokampus (Schacter \& Squire, 1996).

Selain ketidakmampuan memori komputer untuk melakukan pemisahan seperti yang dilakukan otak, memori komputer juga berupa kode yang diubah ke dalam bentuk angka-angka (sistem komputasi tadi). Sementara pada otak manusia, "memori" itu tidak diketahui diubah ke dalam bentuk apa (walaupun sama-sama bekerja dengan listrik, tetap sulit untuk diketahui "memori" itu sendiri ada dalam bentuk apa di otak). Setiap informasi yang masuk ke dalam komputer membutuhkan setidaknya satu tempat ruang penyimpanan (satu berkas, disebut sebagai folder) yang menyebabkan terjadinya "memori penuh" karena kapasitas penyimpanan bergantung secara linier pada jumlah lokasi (Whitworth \& Ryu, 2009). Sementara tidak ada satu sel otak tertentu yang didedikasikan hanya untuk satu memori tertentu; satu memori melibatkan banyak neuron, dengan mungkin 1.000 hingga 1.000.000 lebih neuron per memori (Whitworth \& Ryu, 2009). Atau dapat dikatakan bahwa satu "memori" yang masuk ke otak bukan dikodekan ke dalam satu sel saraf otak saja, melainkan dalam satu pola saraf otak yang saling terintegrasi secara terstruktur. Oleh karena itu, tidak seperti ruang penyimpanan komputer yang bisa "penuh" (full), ruang penyimpanan pada otak manusia justru tidak terbatas karena adanya interkoneksi saraf dari jutaan sel saraf yang ada. Di tambah, setiap memori jangka pendek yang masuk ke otak akan digantikan kembali dengan memori lainnya dan ini mengindikasikan bahwa selalu ada ruang kosong dalam ruang penyimpanan memori di otak tersebut. Sehingga hal ini tetap akan menjadi cukup untuk menjelaskan betapa tak terukurnya kapasitas memori otak manusia.

\section{Neuroteknologi: Sebuah Inovasi Pengembangan dari Neurosains}

Melalui persamaan-persamaan yang ada di antara otak dan komputer, tampaknya tetap memungkinkan bagi neurosains untuk menciptakan dan mengembangkan teknologi yang dapat memiliki kemampuan seperti otak manusia. Hal ini salah satunya diejawantahkan dalam human enhancement, seperti yang dikatakan oleh Nicholas Agar:

"To enhance a human being is to improve him or her. The genetic enhancement of intelligence improves its subject's intelligence by means of modifying genes." (Agar, 2013). 
Sebagian orang mengatakan bahwa prinsip dari human enhancement adalah untuk memperbaiki kekurangan manusia, termasuk memperbaiki fungsi otak. Namun, sebagian yang lain juga mengatakan bahwa human enhancement justru membawa manusia kepada keadaan yang lebih buruk: human enhancement menjadikan manusia seolah-olah bukan manusia (hal ini dapat mengarah pada permasalahan mengenai ontologi manusia: apa dan/atau siapa itu manusia, yang tidak dapat penulis bahas karena keterbatasan ruang). Oleh karena itu, untuk menghilangkan degradasi interpretasi atas human enhancement, perlu dibedakan antara enhancement as improvement dan enhancement for reshaping human beings (atau yang sering disebut pula sebagai enhancement beyond human norms) (Agar, 2013).

Enhancement as improvement merupakan bentuk peningkatan manusia yang sebenarnya tidak bisa dihindari dan ditolak. Pasalnya, kita membutuhkan peningkatan semacam ini untuk menunjang kehidupan kita. Dengan kata lain, enhancement as improvement adalah upaya manusia untuk memperbaiki dirinya. Sebagai contoh, terapi yang diberikan dokter kepada pasien anemia yang mengalami penyakit ginjal kronis. Dokter meresepkan eritropoietin sintetis (EPO) sebagai terapi yang bertujuan untuk memulihkan sel darah merah pasien ke tingkat normal secara biologis (Agar, 2013). Sebaliknya, enhancement for reshaping human being merupakan bentuk peningkatan yang dilakukan melebihi tingkat normal biologis manusia. Misalnya, para pesepeda Tour de France menggunakan EPO untuk tujuan non-terapis, yakni meningkatkan sel darah merah mereka untuk sistem ketahanan tubuh yang unggul sehingga dapat bertahan walaupun jalur sepeda yang dilalui sangat melelahkan (terutama untuk jalur-jalur perbukitan) (Agar, 2013).

Peningkatan-peningkatan ini juga berlaku pada otak manusia. Mungkin sekali pada suatu saat nanti akan ada teknologi tertentu dengan modifikasi genetis yang mampu meningkatkan kinerja otak hingga 1.000 juta mips. Dan seperti yang diprediksikan oleh (Agar, 2013), manusia secara progresif akan mengganti neuron yang rawan penyakit dan rumit secara komputasi dengan chip elektronik yang sangat efisien, termasuk dengan menciptakan perangkat komputasi tiruan yang akan menggantikan fungsi komputasi di otak (dalam hal, perkembangan teknologi sebagai "tiruan otak" akan berkembang secara cepat, disebut sebagai masa singularitas-masa di mana perkembangan teknologi mendominasi kehidupan manusia). Selain itu, salah satu teknologi dalam human enhancement yang juga sedang dikembangkan adalah neuroteknologi.

Tidak bisa dimungkiri bahwa neuroteknologi bukanlah sesuatu yang teramat baru, justru ia telah ada sejak lama dan keberadaannya di mana-mana, bahkan tanpa kita sadari, seperti obat-obat anti-depresan, obat tidur, obat pereda rasa nyeri, obat yang disuntikkan untuk pemindaian penyakit kanker, obat untuk rehabilitasi penyakit stroke, dan lainnya. Neuroteknologi pada umumnya berfungsi merekam dan memecahkan kode sinyal otak untuk berbagai tujuan (Rainey \& Erden, 2020). 
Selain itu, neuroteknologi juga berperan di dalam permrosesan sederhana, tetapi lebih dalam lagi, fungsinya adalah untuk melakukan prediksi, visualisasi, dan analisis data perekaman saraf (Rainey \& Erden, 2020). Bahkan, saat ini para ilmuwan sedang mencoba untuk menciptakan bentuk terbaru dari neuroteknologi yang tidak hanya berfungsi untuk memindai dan merekam aktivitas saraf, tetapi juga melakukan kontrol terhadap kinerja saraf-saraf.

Karena neuroteknologi merupakan bagian dari human enhancement, maka ia juga memiliki dua fungsi: 1) sebagai enhancement as improvement, yakni digunakan dalam tujuan pengobatan seperti halnya di dalam bidang psikiatri yang berkaitan dengan pengontrolan operasi neuron, dan 2) sebagai enhancement for reshaping human being, yakni memperluas fungsi saraf, misalnya dengan melibatkan bagian korteks dalam pengendalian tungkai robotik (Chirimuuta, 2013). Dari dua fungsi ini, diturunkan pengembangan lainnya, yakni BMI (Brain-machine Interfaces) dan BCI (Brain-computer Interfaces). Mengutip Coleman (Coleman, 2018), BMI adalah perangkat yang menerjemahkan informasi saraf menjadi perintah yang mampu mengendalikan perangkat lunak atau perangkat keras eksternal, seperti misalnya gadget impian yang memungkinkan manusia membaca pikiran satu sama lain dan berkomunikasi dengan gelombang otak. Artinya, melalui perekaman sinyal neuron di otak, yang kemudian dihubungkan dengan antarmuka otak-mesin, dapat dihasilkannya keluaran tertentu untuk mengontrol alat-alat yang ingin difungsikan.

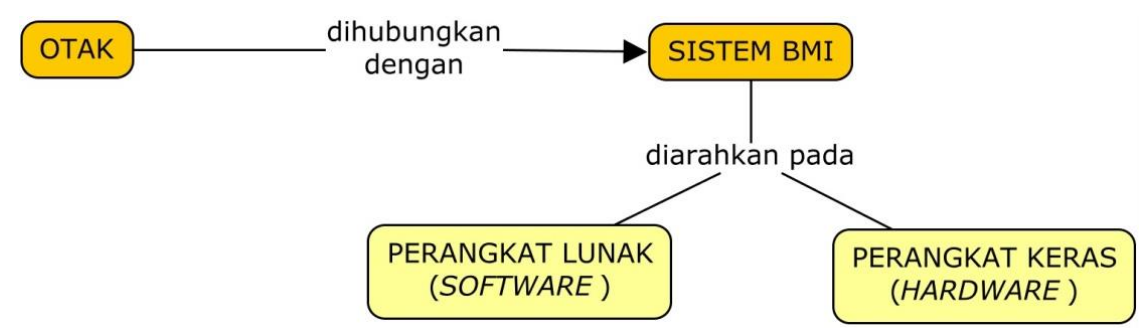

Bagan 2 Sistem BMI

(Diolah sendiri dari berbagai sumber)

Sebaliknya, BCI memberikan masukan (input) pada otak melalui perangkat seperti komputer yang dihubungkan padanya. BCI biasanya dimanfaatkan untuk pengobatan seperti orang yang mengalami lumpuh otak agar bisa berkomunikasi dengan lingkungannya, mengubah cara berpikir seseorang, mengobati penyakit Alzheimer, dan lain sebagainya (Coleman, 2018). BCI juga dapat diterapkan pada mereka yang mengalami gangguan motorik, yakni dengan menghasilkan input berupa pemerosesan data dari komputer. Oleh karena itu, BCI tidak boleh dianggap hanya sebagai antarmuka tambahan (seperti halnya BMI), tetapi juga sebagai sesuatu yang mengubah cara kerja bagian dalam otak dan dengan demikian menambah fungsi baru (Chirimuuta, 2013). 


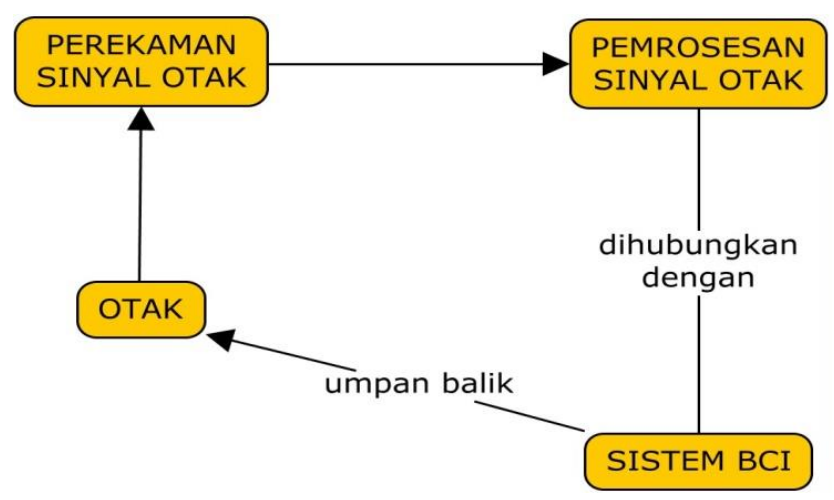

Bagan 3 Sistem BCI

(Diolah sendiri dari berbagai sumber)

Salah satu bentuk BCI yang saat ini sedang dikembangkan adalah neuromodulasi loop tertutup, inovasi dari para peneliti di Departemen Teknik Biomedis Universitas Carnegie Mellon. Neuromodulasi mewakili bidang yang muncul dalam neuroengineering, yakni dengan menyuntikkan energi fisik (misalnya listrik, magnet, akustik) ke otak, sehingga kita dapat mengobati gangguan otak, meningkatkan kualitas hidup, atau bahkan mendeteksi, serta melakukan pencitraan aktivitas otak dan konektivitas. Maka, sama seperti yang telah penulis ungkapkan sebelumnya, keberadaan neuroteknologi pada umumnya adalah sebagai bentuk upaya memperbaiki disfungsi yang terjadi pada otak. Namun, hal ini sebenarnya menimbulkan pertanyaan besar selanjutnya: jika neuroteknologi dapat memperbaiki disfungsi pada otak, apakah neuroteknologi memiliki pengaruh terhadap ingatan seseorang? Apakah seseorang yang kehilangan sebagian atau seluruh ingatannya dapat memiliki kembali ingatan itu secara utuh bila neuroteknologi, katakanlah, berhasil mengatasi disfungsi yang terjadi? Atau kepada pertanyaan yang lebih mendalam lagi: apakah neuroteknologi mampu menggantikan ingatan manusia yang hilang (yang dianggap sebagai akibat dari kerusakan otak)? Salah satu kecurigaan yang dapat diutarakan mengenai keinginan neuroteknologi memperbaiki dan mengganti ingatan manusia itu tampaknya terletak pada pengertian yang tumpang tindih di antara ingatan dan memori. Bisa jadi, apa yang sebenarnya diinginkan oleh neuroteknologi adalah memperbaiki memori manusia, bukan ingatannya. Oleh sebab itu, sebelum melayangkan penegasan apakah neuroteknologi dapat memperbaiki dan mengganti ingatan manusia, perlu diketahui terlebih dahulu makna dari konsep "ingatan" itu sendiri.

\section{Ingatan Sebagai Rekonsepsi "Memori" pada Manusia}

Secara tradisional, "memori" adalah apa pun terutama tentang masa lalu, dalam arti memungkinkan kita untuk mengingat hal-hal yang pernah terjadi (Sant'Anna, 2018). Memori memberikan pengetahuan langsung atau termediasi dari masa lalu (Landesman, 1962); dengan adanya gambar memori (memory image) sebagai sebuah simbol atas apa yang pernah terjadi di masa lalu atau simbol tentang kejadian masa lalu itu sendiri. Memori bukan hanya kemampuan untuk memelihara 
dan mengingat keadaan kesadaran masa lalu atau kemampuan untuk menggambarkan masa lalu sebagai masa lalu, tetapi juga merupakan ekspresi dalam bentuk kebiasaan dan pengalaman masa lalu yang disimpan di dalam otak (Dalla Barba, 2002). Oleh karenanya, memori selalu merujuk pada masa lalu dan bahkan sebagai "sesuatu" yang membentuk masa depan (shaping the future) (Schacter \& Squire, 1996). Namun, istilah "memori" sebenarnya sangat ambigu karena memori itu sendiri dapat merujuk pada banyak hal yang tentunya pernah dialami atau sesuatu yang pernah dipelajari. Apa pun yang kita simpan di dalam otak atau apa pun yang kita miliki dalam otak itu, bisa merepresentasikan apa yang disebut sebagai memori. Seperti yang dikatakan oleh Broad:

"Even apart from these odd senses of "memory" it is quite certain that the word covers a number of very different acts. We talk of remembering a set of nonsense-syllables; of remembering a poem; of remembering a proposition in Euclid, though we have forgotten the words in which it was expressed when we originally learnt it; of remembering past events, and of remembering people, places, and things." (Broad, 1925).

Lebih lanjut, berdasarkan perbedaannya dengan memori komputer, dapat diketahui bahwa memori manusia ternyata memiliki arti yang perlu diselidiki lebih mendalam. Pasalnya, memori komputer dan memori manusia memiliki kemiripan: ketika saya mengatakan bahwa saya memiliki memori tentang apel, berarti saya tahu tentang apel, begitu juga dengan memori komputer yang dapat menyimpan informasi mengenai apel (apa itu apel, ciri-cirinya, dan karakteristiknya). Hemat penulis, memori komputer dan memori manusia itu sama dalam hal data-data informasi. Manusia dan komputer sama-sama memiliki memori yang merujuk pada segala pengetahuan faktual, informasi, dan/atau data-data tertentu. Selain itu, perlu ditekankan bahwa memori berbeda dengan ingatan, tetapi ia mencakup apa yang disebut sebagai ingatan. Memori tidaklah selalu mengenai ingatan, tetapi ingatan mau bagaimana pun adalah bagian dari memori. Sebagai contoh, ketika saya mengatakan bahwa saya memiliki ingatan tentang apel, berarti saya mungkin tidak tahu apel, tetapi saya memiliki perasaan tertentu ketika ingatan saya terbawa pada apel. Inilah yang disebut sebagai ingatan yang dibedakan dengan memori.

Dalam kategori hirarkis, memori manusia dibedakan ke dalam dua macam, yakni memori deklaratif dan memori non-deklaratif. Menurut Werning \& Cheng, dua macam memori ini juga disebut sebagai memori yang dapat diartikulasikan dan memori yang tidak dapat diartikulasikan, serta disebut pula sebagai memori eksplisit dan memori implisit (Bernecker \& Michaelian, 2017). Untuk memori nondeklaratif, dapat dipahami melalui contoh: saat seseorang belajar mengendarai mobil untuk yang pertama kali, seseorang diajarkan bagian-bagian mobil dan fungsinya, serta juga diajarkan caranya mengemudi. Namun, apa yang tidak bisa diartikulasikan adalah bagaimana ia melakukan pengamatan, perhitungan, "observasi", misalnya dengan mendeteksi dan memprediksi keseimbangan saat berkendara, menghitung dan memperkirakan apakah ia akan bertabrakan dengan 
pengendara lainnya di jalan. Menurut (Bernecker \& Michaelian, 2017) memori non-deklaratif merupakan kesadaran anoetik, yakni kita sadar akan kemampuan suatu keterampilan tertentu, tetapi tidak menyadari isi ingatan kita tentang keterampilan itu. Ada pula yang mengartikan memori non-deklaratif sebagai memori praktis (practical memory) di mana seseorang dapat mengingat atau mengetahui cara mengemudikan mobil yang berarti sama dengan dapat melakukannya (Rabb, 1972).

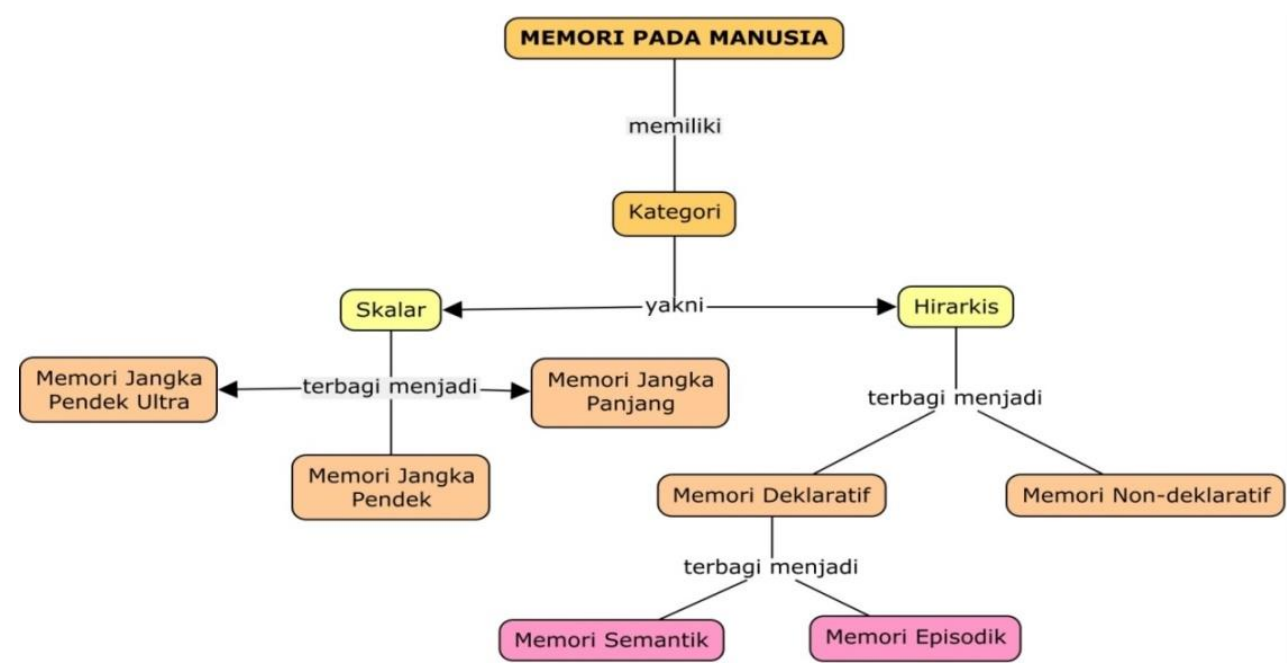

Bagan 3 Kategori Memori pada Manusia Sumber: (Bernecker \& Michaelian, 2017)

Memori deklaratif dibagi ke dalam dua jenis, yakni memori semantik dan memori episodik. Memori semantik disebut juga sebagai "pengetahuan umum" kita tentang dunia (our knowledge about the world outside), sedangkan memori episodik disebut sebagai memori atas peristiwa yang pernah dialami secara pribadi (memory about our personal events or experiences). Keduanya adalah bagian dari memori jangka panjang karena tersimpan di dalam otak manusia dalam kurun waktu yang lama, bahkan hingga seumur hidup. Jika memori non-deklaratif dikategorikan oleh Tulving sebagai kesadaran anoetik, maka memori semantik dan memori episodik ia sebut sebagai kesadaran noetik dan kesadaran autonoetik (Bernecker \& Michaelian, 2017). Kesadaran noetik disebut juga sebagai kesadaran seseorang akan suatu objek atau peristiwa di mana objek atau peristiwa itu tidak pernah dialaminya secara langsung. Sementara kesadaran autonoetik ialah kesadaran akan objek atau kejadian yang pernah dialami sebelumnya. Contohnya, saya ingat hari di mana saya makan malam dengan ayah saya di sebuah restoran pinggir danau. Saya ingat sekali kapan tepatnya dan seperti apa suasananya. Semua yang pernah saya alami ini disebut sebagai ingatan. Ingatan inilah yang membedakan memori manusia dengan memori komputer. Ingatan adalah memori personal tentang apa yang saya ingat terkait segala hal, manusia, tempat, benda- 
benda, kejadian, ataupun situasi yang secara personal pernah saya alami (Rabb, 1972). Sementara apa yang disimpan di dalam komputer ialah sejenis dengan memori manusia yang lainnya, yakni memori semantik yang berupa data-data informasi, termasuk di dalamnya kemampuan berbahasa. Memori semantik ini yang seringkali dapat "dipertukarkan" antara komputer dan manusia, dalam arti ia menjelaskan apa itu kecerdasan. Hal ini dikarenakan memori semantik adalah memori yang berkaitan erat dengan representasi, dalam arti, representasi dari sistem komputasi yang disebut sebagai sistem representasi internal (kumpulan dari berbagai mental symbols). Seperti yang juga telah disinggung sebelumnya, komputer dan otak sama-sama "bergerak" di dalam sistem komputasi ini, di mana keduanya dapat mengolah representasi, sehingga kita bisa menyebut komputer yang dapat berbicara sebagai mesin yang memiliki kecerdasan, sama seperti manusia. Oleh karena itu, dari pembedaan antara memori semantik dan memori episodik ini, juga dapat mengarahkan pada adanya perbedaan antara mengetahui dan mengingat.

Kembali pada contoh pengalaman 'saya' di atas, saya mungkin bisa berbagi memori personal itu dengan menceritakannya kepada sahabat saya hingga ke setiap detailnya dan sahabat saya mungkin bisa membayangkan apa yang saya lalui pada hari itu, hingga ke setiap detail yang saya paparkan, tetapi ia tidak bisa memiliki perasaan yang sama seperti yang saya rasakan. Artinya, memori saya tentang masa lalu adalah milik saya karena ia bersifat personal. Apa yang didapatkan oleh sahabat saya dari cerita itu bukanlah memori personal yang sama, melainkan "pengetahuan" (knowledge). Sehingga dapat dikatakan bahwa saya yang memiliki memori personal adalah saya yang ingat (I remember), sementara fakta apa yang didapatkan oleh sahabat saya tentang hal yang saya alami adalah sebagai saya yang tahu (I know). Tulving menyebutnya sebagai "the rememberer", yakni orang yang mengingat yang mengalami pengalaman subjektif itu (Schacter \& Squire, 1996) Oleh karenanya, dapat dirumuskan bahwa "lawan" dari memori personal ialah memori-pengetahuan (memory-knowledge).

Berdasarkan penjelasan di atas mengenai ingatan, maka mau tidak mau kita akan memahami ingatan sebagai sesuatu yang berkaitan erat dengan afeksi, termasuk di dalamnya emosi. Ketika berbicara mengenai memori dan emosi, berarti ada memori episodik yang ikut terlibat di dalamnya (Bernecker \& Michaelian, 2017) dan memori episodik ini yang paling memadai untuk merepresentasikan apa itu ingatan. Seperti yang juga telah dijelaskan, ingatan adalah bentuk dari memori personal, sehingga dapat dipahami bahwa si pengingat (the rememberer) mengalami langsung kejadian yang ia ingat. Dengan kata lain, ingatan tidak bisa lepas dari persepsi; apa yang kita ingat adalah apa yang kita persepsi. Apa yang diingat adalah apa yang telah dirasakan atau dialami; apa pun yang kita rasakan adalah sesuatu yang mungkin kita ingat (Landesman, 1962). Maka, dapat dikatakan bahwa segala ingatan yang menjadi sebuah episode di dalam memori seseorang adalah pengejawantahan dari sesuatu yang pernah diperolehnya, dan dalam hal ini, persepsi adalah salah satu cara bagaimana seseorang memperoleh sesuatu. 
Mempersepsi ialah bentuk mengetahui dan mengalami hal yang sebelumnya tidak diketahui dan tidak dialami, sementara mengingat adalah upaya mengetahui dan mengalami kembali sesuatu yang pernah ia ketahui dan ia alami (sesuatu yang pernah ia dapatkan dari mempersepsi). Itulah mengapa ingatan berbeda dengan memori semantik. Karena seseorang tidak perlu mempersepsi untuk mengetahui fakta berapa kecepatan cahaya, sementara seseorang perlu mempersepsi untuk dapat mengingat apa yang pernah ia alami sebelumnya.

Mempersepsi membuat kita memiliki perasaan tertentu yang sangat subjektif, sehingga orang lain belum tentu merasakan apa yang kita rasakan. Ketika seseorang ingat tentang sesuatu, ia pasti merasakan tentang sesuatu tersebut, tetapi belum tentu seseorang bisa mengekspresikan apa yang ia rasakan itu, bahkan ketika ia mencoba menceritakannya kepada orang lain. Dengan demikian, kita akan jatuh pada pembicaraan mengenai qualitative states yang disebut sebagai qualia.

"Let us suppose that you are, right now, getting the unmistakable smell of fresh coffee drifting in from the kitchen. The smell may be caused by chemical entering your nose and reacting with receptors there, but as far as you are concerned the experience is nothing to do with chemicals. You probably cannot describe it even to yourself. It is just how fresh coffee smells. The experience is private, ineffable and has a quality all its own. These private qualities are known, in philosophy, as qualia." (Blackmore, 2013).

Qualia adalah bagaimana rasanya ketika memiliki mental states tertentu; ia adalah bentuk experiential properties dari sensasi, perasaan, hasrat, pikiran, dan termasuk juga di dalamnya persepsi. Oleh karenanya, ketika mengingat sesuatu, pasti sesuatu yang diingat adalah sesuatu yang pernah dipersepsi sehingga menghasilkan rasa tertentu. Memori episodik mengacu pada masa lalu ("feeling of pastness") dan menjadi bagian dari subjek dengan cara yang unik ("feeling of warmth and intimacy") (Sant'Anna, 2018). Kendati kita menceritakan apa yang diingat kepada orang lain dan orang lain (diasumsikan) memiliki perasaan yang sama, tidak ada yang bisa mengatakan dan membuktikan dengan jelas bahwa apakah yang ia rasakan sama seperti apa yang kita rasakan karena qualitative states itu bersifat subjektif dan milik pribadi. Kita mungkin bisa mengatakannya pada orang lain, tetapi kata-kata tidak akan pernah cukup untuk menggambarkan seperti apa rasanya saat memegang sebuah pensil, saat mempersepsi sesuatu, dan seperti inilah qualia itu (Blackmore, 2013). Oleh karenanya, memori episodik dapat dikatakan sebagai sarat qualia (qualia-laden) (Ramachandran, V., \& Hirstein, 1997), sehingga dapat digarisbawahi bahwa memori manusia berbeda dari memori komputer; memori komputer ialah jenis dari memori semantik yang tidak memiliki qualia, sementara memori manusia juga merujuk pada ingatan (memori episodik) yang merupakan sarat dari qualia, atau memiliki qualitative states. Hemat penulis, memori episodik bersifat privilege access, dalam arti hanya kita yang memiliki akses atas pikiran kita sendiri, hanya saya yang memiliki akses secara langsung atas ingatan saya, sehingga inilah yang dimaksud memori episodik dengan "otoritas 
orang pertama": tidak ada yang bisa menjamahnya, kecuali diri saya sendiri. Oleh karena itu, permasalahan qualia dan/atau qualitative states yang melibatkan mental of feelings, sensations, perceptions, dan desires, menjadi sangat penting untuk digarisbawahi dalam kaitannya dengan memori episodik (ingatan) karena ia dapat "memberi penjelasan" mengapa memori episodik pada akhirnya berada dalam ranah privat orang pertama sehingga permasalahan mengenai ingatan ini menjadi begitu krusial. Lantas, kembali lagi, apakah neuroteknologi dapat memperbaiki dan mengganti memori episodik atau ingatan manusia itu? Untuk menjawab pertanyaan ini, ternyata perlu ditelaah lebih jauh mengenai hubungan di antara neuroteknologi dan ingatan manusia.

\section{Neuroteknologi dan Ingatan Manusia}

Pada bagian sebelumnya, penulis telah menyinggung bahwa Brain-computer Interfaces (BCI) dapat mengobati disfungsi otak akibat penyakit Alzheimer. Salah satu akibatnya adalah seseorang kehilangan kemampuannya dalam mengingat, atau disebut juga sebagai amnesia. Sindrom amnesia adalah kondisi patologis yang serius dari kehilangan ingatan setelah kerusakan otak dan mungkin merupakan salah satu sindrom neuropsikologis yang paling melemahkan (Dalla Barba, 2002). Seseorang yang mengalami amnesia dapat kehilangan seluruh atau sebagian ingatannya. Namun, bukan berarti orang yang hilang ingatan menjadi nothing. Banyak dari mereka yang masih tahu cara duduk, cara menggerakkan anggota tubuh, bahkan masih tahu cara berbicara dan berbahasa. Ini adalah memori semantik yang mereka miliki sebagai bentuk dari memory-knowledge yang masih tersimpan. Seperti yang juga dikatakan oleh Tulving (Dalla Barba, 2002), orang yang amnesia menunjukkan adanya kekurangan memori episodik dengan tidak hanya kehilangan kemampuan masa lalunya, tetapi juga tidak dapat menempatkan diri mereka (mode refleksif kesadaran temporal) dan objek (mode kesadaran temporal non-refleksif) dalam dimensi temporalitas yang disebut masa lalu, bahkan mereka pun tidak mampu menempatkan diri dan objeknya di masa kini atau di masa depan. Barba kembali menegaskan:

"That patient, as is usually the case in amnesics, had preserved all his socalled semantic knowledge, namely knowing consciousness, but was not capable of recalling any episode of his own past nor of saying anything at all about his future. When he was asked what he had done shortly before or the previous day, or what he would do the following day his answer was "I don't know". When asked to describe his state while trying to remember the past or to predict the future he would say that it was as though there were a blank." (Dalla Barba, 2002).

Dengan kata lain, orang yang mengalami amnesia kehilangan (seluruh atau sebagian) memori episodik yang mengantarkannya pada masa lalu, juga pada proyeksi masa depan. Oleh karenanya, ini menjadi salah satu latar belakang mengapa diciptakannya neuroteknologi yang (dianggap) mampu mengatasi kerusakan otak, hingga memperbaikinya. Hanya saja, tebersit pertanyaan: apakah memperbaiki otak manusia sama dengan mengembalikan ingatan yang telah 
hilang? Apakah neuroteknologi dapat menjamin kembalinya ingatan manusia seperti pada saat ia memilikinya tanpa gangguan?

Kita bisa menilai bahwa permasalahan ingatan adalah sesuatu yang sangat kompleks karena melibatkan persepsi, rasa, dan subjektivitas. Bahkan, kalaupun bisa diciptakannya neuroteknologi yang melengkapi segala kompleksitas itu, tampaknya ini menjadi pekerjaan yang amat berat karena ingatan setiap orang berbeda-beda, akibat dari pengalaman perseptual yang berbeda-beda pula. Kemudian, seperti yang juga telah dijelaskan, ingatan bukanlah memori semantik, sebab ingatan melibatkan persepsi. Persepsi ini yang menghasilkan pengalaman rasa yang berbeda-beda pada tiap individu, menghasilkan qualitative states yang berbeda-beda antara satu manusia dan manusia lainnya, walaupun dihadapkan dengan misalnya, jika harus, situasi yang sama atau ingatan yang sama sekali sama. Jika neuroteknologi berupaya untuk memperbaiki dan mengganti ingatan manusia, maka bisa diartikan bahwa neuroteknologi berupaya untuk memperbaiki dan mengganti qualitative states yang sama dan/atau identik dengan qualitative states yang dimiliki sebelum ingatan itu memudar atau lenyap. Kita bisa membayangkan neuron yang mengalami kerusakan digantikan dengan sebuah chip elektronik yang terbuat dari silikon dan memiliki fungsi yang sama sekali sama dengan neuron itu. Eksperimentasi pikiran ini yang juga digunakan oleh Chalmers untuk menegaskan bahwa fading qualia adalah suatu kemasukakalan dan sangat mungkin bisa diterima.

"We can imagine, for instance, replacing a certain number of my neurons by silicon chips. In the first such case, only a single neuron is replaced. Its replacement is a silicon chip that performs precisely the same local function as the neuron. Where the neuron is connected to other neurons, the chip is connected to the same neurons. Where the state of the neuron is sensitive to electrical inputs and chemical signals, the silicon chip is sensitive to the same." (Chalmers, 1996).

Pada intinya, chip elektronik yang terbuat dari silikon itu memiliki fungsi dan cara kerja yang sama sekali identik dengan neuron di otak. Neuron-neuron di otak secara perlahan diganti dengan chip tersebut, hingga pada akhirnya, seluruh neuron di otak digantikan dengannya. Kita bisa menganggap bahwa, terutama dalam kasus orang sebelum mengalami lupa ingatan, memiliki ingatan yang membawanya pada rasa tertentu, yakni misalnya perasaan saat mengingat liburan ke suatu tempat pada tahun lalu. Kemudian, saat orang itu mengalami gangguan pada neuron-neuronnya dan digantikan perlahan dengan chip elektronik tadi, ternyata ingatannya kembali. Pertanyaannya, apakah ingatannya yang kembali itu sama dengan ingatan saat ia masih memiliki neuron secara normal, bukan dengan chip elektronik yang diimplan ke dalam otaknya? Apakah rasa ingatan mengenai liburan ke suatu tempat pada tahun lalu sebelum dan sesudah digantikan dengan chip elektronik adalah sama? Apakah ada perbedaan rasa antara seseorang sebelum amnesia dan orang yang ingat kembali ingatannya dengan "dibantu" oleh chip elektronik? 
Dalam hal ini, kita seolah-olah atau memang sedemikian ditunjukkan bahwa adanya keterhubungan di antara hal-hal yang fisik dan dan hal-hal yang mental, bahwa sesuatu yang mental (seperti memori episodik atau kesadaran autonoetik) terhubung dengan sesuatu yang fisik (yakni otak dan neuron-neuron di dalamnya). Seperti yang juga dikatakan oleh Chalmers, kita mungkin memiliki alasan yang kuat untuk percaya bahwa kesadaran itu muncul dari sistem fisik seperti otak, tetapi kita hanya memiliki sedikit gagasan bagaimana ia dapat muncul, atau mengapa ia ada sama sekali (Chalmers, 1996) dan tampaknya kita tidak hanya kekurangan teori rinci, tetapi kita memang sepenuhnya tidak tahu bagaimana kesadaran cocok dengan tatanan alam (natural order) (Chalmers, 1996). Hemat penulis, kita tidak tahu bagaimana otak dapat menghasilkan ingatan atau memori episodik yang begitu elusif untuk dijelaskan, terlebih karena ia menyangkut qualia, lantas bagaimana mungkin dapat dibuat teknologi yang dapat menghasilkan ingatan, apalagi mengganti ingatan yang hilang?

Sebagai penegasan, seseorang bisa mengatakan bahwa ingatannya tentang liburan ke suatu tempat pada tahun lalu amat menyenangkan, rasanya sama seperti saat melihat pemandangan hijau kaki gunung. Namun, pada otak yang telah diimplan "sistem baru" ke dalamnya, bisa jadi ia mengalami rasa ingatan yang berbeda: seseorang itu bisa merasakan hal yang menyenangkan atas liburan ke suatu tempat tahun lalu, tetapi rasanya seperti saat melihat tepi pantai, bukan pemandangan hijau kaki gunung. Atau, bisa jadi ia mengalami rasa ingatan yang justru tidak menyenangkan, tetapi menyedihkan atau menakutkan. Mungkin saja ia terbawa pada perasaan-perasaan yang sangat jauh berbeda dari sebelum ia mengalami amnesia. Dalam hal ini, qualia memiliki "jenis" yang berbeda dari dua ingatan yang berbeda, misalnya. Artinya, satu ingatan yang seseorang ingat, tidak sama rasanya dengan ingatan lainnya yang ia ingat. Dengan kata lain, neuroteknologi, tampaknya, melakukan generalisasi bahwa orang-orang yang mengalami amnesia adalah orang-orang yang memiliki ingatan yang sama, atau ada anggapan bahwa semua orang yang mengalami pemudaran ingatan atau kehilangan total ingatannya berarti mengacu pada ingatan yang sama. Padahal, diketahui bahwa ingatan satu orang dengan objek ingatan yang berbeda memiliki "kualitas" yang juga berbeda; qualia mengingat liburan ke pantai tidak sama dengan qualia mengingat liburan ke puncak.

Kembali pada neuron yang digantikan dengan chip elektronik, ternyata rangkaian penggantian itu tidak menyebabkan kehilangan qualia secara tiba-tiba, tetapi pemudaran qualia seperti yang dikatakan oleh Chalmers. Kesadaran secara bertahap memudar selama serangkaian kasus (menggantikan neuron dengan chip elektronik silikon itu), sebelum akhirnya menghilang (Chalmers, 1996), dalam arti, seseorang bisa memiliki ingatan yang berbeda atau sama sekali tidak adanya ingatan itu lagi. Bahkan, mungkin bisa ditarik lebih jauh: jika neuron yang rusak saja dapat digantikan dengan neuroteknologi, apakah berarti mungkin untuk menciptakan robot yang terdiri dari serangkaian chip elektronik yang benar-benar 
sama dengan neuron di otak? Jika iya, apakah robot itu bisa memiliki ingatan? Hal ini tampaknya cukup menjelaskan bahwa keinginan mengganti neuron dengan chip elektronik berarti mereduksi hal mental ke dalam sesuatu yang fisik, atau sesuatu yang mental ada (hadir setelah) sesuatu yang fisik (the mental supervence on the physical). Memang bisa dikatakan bahwa hal mental itu dibangun dari hal yang fisik, tetapi hal mental tidak dapat direduksi dari hal yang fisik. Bahkan, problematika mengapa hal yang mental itu terhubung atau dibangun dari hal yang fisik tidak terjawab, lantas bagaimana mungkin hal yang mental itu dapat direduksi ke dalam hal yang fisik?

Lebih jauh, saya mungkin bisa membayangkan adanya suatu entitas yang benar-benar identik dengan diri saya, yang disebut Chalmers sebagai zombie twin. Secara fisik, zombi kembaran ini sangat identik dengan saya, tetapi identik dalam arti analisis fungsional, yakni ia akan terjaga, mampu melaporkan isi keadaan internalnya, mampu memusatkan perhatian di berbagai tempat, dan sebagainya (Chalmers, 1996). Akan tetapi, ia tidak memiliki pengalaman kesadaran yang nyata, tidak memiliki atau tidak adanya perasaan fenomenal.

"A zombie is just something physically identical to me, but which has no conscious experienceall is dark inside." (Chalmers, 1996).

Dalam hal ini, jika kembaran zombi tanpa pengalaman sadar dapat dibayangkan, maka kita hanya perlu mengganti silikon dengan neuron dalam konsepsi sambil membiarkan organisasi fungsional tetap konstan, tetapi implementasional ini sama sekali bukan jenis hal yang secara konseptual relevan dengan pengalaman (Chalmers, 1996), sehingga dapat dikatakan bahwa the mental is not logically supervence on the physical. Pada akhirya, harus diakui bahwa hal ini ternyata memang sulit untuk dijelaskan. Kembali kepada apa yang ingin diangkat, yakni apa yang sebenarnya membuat kita benar-benar yakin bahwa neuroteknologi bisa memperbaiki dan mengganti ingatan manusia? Bahkan, ingatan yang menghadirkan qualitative states masih merupakan hal yang misterius mengapa dapat dihasilkan dari reaksi fungsi-fungsi di otak (kerusakan yang terjadi pada bagian-bagian otak memang mempengaruhi ingatan seseorang, yang artinya juga mempengaruhi qualitative states sebagai karakteristik dari ingatan itu. Akan tetapi, permasalahan mengapa fisik dapat mempengaruhi ingatan hingga akhirnya memengaruhi "kualitas" ingatan itu sendiri tidak bisa dijelaskan). Penolakan ini juga datang dari mereka yang menolak posibilitas implan chip elektronik sebagai pengganti neuron otak. Ada yang bahkan mengatakan bahwa teknologi semacam ini hanyalah produk science fiction, tidak nyata sama sekali. Atau kembali lagi, chip elektronik secanggih apa pun dibuat, tidak pernah bisa melakukan fungsi seperti apa yang dilakukan oleh neuron di otak. Hemat penulis, model seperti chip elektronik atau jaringan saraf tiruan tetap merupakan penyederhanaan kasar dari aktivitas saraf biologis yang ingin dimodelkan dan secara khusus gagal untuk memperhitungkan efek global dan analog dari neurotransmitter semisal, dan ini memiliki implikasi yang mendalam untuk kemungkinan pemodelan sejumlah 
fenomena mental, termasuk (yang terpenting) adalah pada perhatian dan emosi (juga sensasi, perasaan, dan mood) (Carter, 2007). Selain itu, sistem saraf belum tentu merupakan substrat fisik bagi pikiran (Manzotti \& Moderato, 2010). Dengan kata lain, neuroteknologi seperti halnya jaringan saraf tiruan atau chip elektronik yang diharapkan dapat menggantikan neuron di otak, bukanlah replika dari otak manusia, melainkan hanya model atau simulasi mengenai otak manusia.

\section{Kesimpulan}

Neuroteknologi seolah-olah memberikan harapan bahwa suatu saat akan ada kemungkinan memperbaiki dan mengganti ingatan manusia yang rusak atau bahkan hilang. Hal ini terlihat melalui eksperimentasi pikiran di mana sebuah chip elektronik terbuat dari silikon akan menggantikan segala proses yang dilakukan oleh neuron ketika neuron itu rusak. Akan tetapi, bagaimana pun, chip elektronik semacam ini tetaplah hanya model dan/atau simulasi terhadap neuron, bukan replika. Sehingga, neuroteknologi lagi-lagi hanyalah bentuk penyederhanaan kasar dari segala proses biologis yang terjadi di dalam otak, bukan suatu "hal" yang dapat dianggap sama dengan segala fungsi dan aktivitas neuron yang ada, bahkan bentuk pemodelan komputasi tercanggih dan terbaik yang ada pada saat ini masih tetap tidak memadai untuk menyerupai dan mengganti proses komputasi otak manusia, kendati terus memberikan harapan kepada para ilmuwan untuk menciptakan pemodelan AI yang kuat dan sukses. Hanya saja, hal ini tetap menunjukkan bahwa neuroteknologi, khususnya, tetap jauh dari kata mungkin untuk dapat memperbaiki dan mengganti ingatan manusia. Selain dari ketidakmungkinan logis dibuatnya teknologi yang sama sekali identik dengan neuron, pemahaman para ahli akan segala struktur dan fungsi otak juga tidak menjamin bahwa mungkin untuk membuat sesuatu yang dapat berperan layaknya otak itu sendiri. Sangat mungkin bahwa memahami pikiran tidak membutuhkan pemahaman otak, misalnya, kita bisa saja memahami suatu program tertentu tanpa mengetahui apa pun tentang implementasi elektroniknya di komputer kita, bahkan kita bisa mengabaikan atau tidak mengetahui merek komputer kita sendiri. Dengan kata lain, jika pemahaman tentang otak saja tidak cukup bagi kita untuk memahami isi pikiran atau memahami pikiran tidak berarti harus memahami bagian-bagian otak dan fungsinya, bagaimana mungkin dapat diciptakan neuroteknologi yang benar-benar dapat memperbaiki dan mengganti ingatan kita yang rusak atau hilang? Hal ini membuat kita kembali kepada permasalahan mengenai ingatan atau memori episodik dan segala karakteristiknya, yakni qualia dan/atau qualitative states. Pemahaman qualitative states melalui penjelasan dan pemahaman akan otak sangatlah tidak cukup untuk menjelaskan hubungan mind dan body, artinya selalu ada gap yang tidak pernah bisa dijelaskan di antara keduanya. Sehingga permasalahan seperti ingatan tidak mudah untuk dipahami dan menjadi sesuatu yang elusif. Mungkin, akan ada yang mengatakan bahwa semua ini hanyalah "permasalahan waktu", dalam arti, hanya karena saat ini memang belum ada teknologi yang memadai untuk menjawabnya. Akan tetapi, hal itu tentu bukanlah jawaban mengenai ketidakmungkinan logis, melainkan jawaban sains yang tentunya 
bukan merupakan fokus penelitian di dalam tulisan ini. Penegasannya adalah dengan kembali pada memori episodik sebagai "karakteristik" manusia yang sebenarnya tidak bisa digantikan oleh apa pun, termasuk di dalamnya teknologi yang paling canggih. Oleh karena itu, sebesar apa pun upaya neuroteknologi mencoba untuk memperbaiki dan mengganti ingatan manusia, tampaknya hal ini menjadi sulit, atau bahkan tidak mungkin sama sekali untuk direalisasikan.

\section{BIBLIOGRAFI}

Agar, Nicholas. (2013). Truly human enhancement: a philosophical defense of limits. MIT Press.

Bernecker, Sven, \& Michaelian, Kourken. (2017). The Routledge handbook of philosophy of memory. Routledge.

Blackmore, Susan. (2013). Consciousness: an introduction. Routledge.

Broad, C. D. (1925). The Mind and its Place in Nature, Kegan Paul, Trench and Trubner. Harcourt, Brace, Londres/Nueva York.

Carter, Matt. (2007). Minds and computers: An introduction to the philosophy of artificial intelligence: An introduction to the philosophy of artificial intelligence. Edinburgh University Press.

Chalmers, David J. (1996). The conscious mind: In search of a fundamental theory. Oxford Paperbacks.

Chirimuuta, Mazviita. (2013). Extending, changing, and explaining the brain. Biology \& Philosophy, 28(4), 613-638.

Coleman, Jeff. (2018). Brain Computer Interfaces with Artificial Intelligence and Reinforcement Learning. Medium. Com Blog.

Dalla Barba, Gianfranco. (2002). The Homunculus Fallacy. In Memory, Consciousness and Temporality (pp. 27-85). Springer.

Daly, Christopher. (2010). An introduction to philosophical methods. Broadview Press.

Fosl, Peter S., \& Baggini, Julian. (2020). The philosopher's toolkit: A compendium of philosophical concepts and methods. John Wiley \& Sons.

Landesman, Charles. (1962). Philosophical problems of memory. The Journal of Philosophy, 59(3), 57-65.

Manzotti, Riccardo, \& Moderato, Paolo. (2010). Is Neuroscience Adequate as the Forthcoming" Mindscience"? Behavior and Philosophy, 1-29. 
Nematzadeh, Aida, Ruder, Sebastian, \& Yogatama, Dani. (2020). On memory in human and artificial language processing systems. Proceedings of the Bridging AI and Cognitive Science Workshop at ICLR.

Rabb, J. Douglas. (1972). Memory, by Don Locke. Toronto: Macmillan Press Ltd. 1971. Pp. 145. \$6.50. Dialogue: Canadian Philosophical Review/Revue Canadienne de Philosophie, 11(3), 472-475.

Rainey, Stephen, \& Erden, Yasemin J. (2020). Correcting the Brain? The Convergence of Neuroscience, Neurotechnology, Psychiatry, and Artificial Intelligence. Science and Engineering Ethics, 26(5), 2439-2454.

Ramachandran, V., \& Hirstein, W. (1997). Three Laws of Qualia. Journal of Consciousness Studies, 4(5-6), 429-458.

Sant'Anna, André. (2018). Mental time travel and the philosophy of memory. Filosofia Unisinos, 19(1), 52-62.

Santagata, Sandro, Eberlin, Livia S., Norton, Isaiah, Calligaris, David, Feldman, Daniel R., Ide, Jennifer L., Liu, Xiaohui, Wiley, Joshua S., Vestal, Matthew L., \& Ramkissoon, Shakti H. (2014). Intraoperative mass spectrometry mapping of an onco-metabolite to guide brain tumor surgery. Proceedings of the National Academy of Sciences, 111(30), 11121-11126.

Schacter, Daniel L., \& Squire, Larry R. (1996). Searching for Memory: The Brain, the Mind and the Past. Nature, 382(6591), 503.

Whitworth, Brian, \& Ryu, Hokyoung. (2009). A comparison of human and computer information processing. In Encyclopedia of Multimedia Technology and Networking, Second Edition (pp. 230-239). IGI Global. 